\title{
Koncepcja ekorozwoju w ujęciu Stefana Kozłowskiego
}

\section{Wprowadzenie}

Pojęcie ekorozwoju zostało sformułowane w roku 1975 na III Sesji Zarządzającej Programem Ochrony Środowiska ONZ (UNEP). Przyjęto wtedy, że „społeczeństwo realizujące ideę ekorozwoju: uznaje nadrzędność wymogów ekologicznych, których nie należy zakłócać przez wzrost cywilizacji oraz rozwój kulturalny i gospodarczy, jest zdolne do samosterowania swoim rozwojem w celu utrzymania homeostazy i symbiozy z przyrodą, a więc respektuje oszczędną produkcję i konsumpcję oraz wykorzystywanie odpadów, dba o przyszłościowe konsekwencje podejmowanych działań, a więc także o potrzeby i zdrowie przyszłych pokoleń"1.

To ogólne przesłanie znalazło swoją kontynuację w kolejnych dokumentach opracowywanych pod auspicjami ONZ - m.in. w: Światowej strategii ochrony przyrody (1980). Dokument ten precyzował cele ochrony żywych zasobów dla trwałego rozwoju w następujących postulatach:

a) Utrzymanie podstawowych procesów ekologicznych i systemów będących ostoją życia.

b) Zachowanie różnorodności genetycznej.

c) Zapewnienie trwałego użytkowania gatunków i ekosystemów.

Zawarte w przyjętej w 1982 roku przez Zgromadzenie Ogólne ONZ Światowej Karcie Przyrody podstawowe zasady wprowadzały powinność szanowania przyrody oraz eliminację złego wpływu na jej istotne procesy. Dotyczyły również ochrony zdolności genetycznej życia na Ziemi. Przyjęto przy tym, że populacja każdego gatunku dzikiego lub udomowionego będzie utrzymana, co najmniej na poziomie wystarczającym do przeżycia, a środowiska potrzebne do tego celu będą chronione. Podkreślono, że zasady ochrony będą zastosowane do każdej części powierzchni globu, lądu lub morza, a specjalna ochrona będzie przyznana zasobom, które są unikatowe. Należą do nich wzorce reprezentatywne

S. KozŁowski, Ekorozwój. Wyzwanie XXI wieku, Warszawa 2002, s. 106. 
całych ekosystemów zróżnicowanych typów oraz siedliska gatunków rzadkich lub zagrożonych. Tak sformułowane zasady mają przyczyniać się do tego, aby ekosystemy i organizmy, tak samo jak zasoby lądowe, morskie i atmosferyczne, które użytkuje człowiek, były zachowane w taki sposób, aby zapewnić i utrzymać ich optymalną i ciągłą produktywność. Powinno to być realizowane bez narażania innych ekosystemów lub gatunków, z którymi one współistnieją. Przyroda winna być zabezpieczona przed pustoszeniem powodowanym przez wojnę lub inne wrogie, względem niej, działania.

$\mathrm{W}$ idei ekorozwoju dostrzega się także potrzebę przemiany strategii gospodarczego rozwoju świata. Zagadnienia te prezentowane były w kolejnych raportach Klubu Rzymskiego (Meadows i in., 1973; 1995²). Coraz częściej postuluje się konieczność zmiany dotychczasowych priorytetów gospodarczych i politycznych. Tematyka ta znajduje swoje odzwierciedlenie w licznych opracowaniach jak np. w Raportach o stanie świata, przedstawiających stanowisko World - Watch Institute na temat szans przetrwania ludzkości.

Stefan Kozłowski wskazuje, że pojęcie zrównoważonego rozwoju przeciwstawia się dotychczas przyjmowanej teorii wzrostu gospodarczego. Koncepcja ta, bowiem, zakłada, że gospodarkę kraju należy prowadzić zgodnie z naturalnymi uwarunkowaniami przyrodniczymi. Aby wariant ekologiczny był realizowany, w kształtowaniu przestrzeni kraju winny być stosowane prawa ekologii. Realizowane powinny być również zasady gospodarowania oparte o te prawa. Jak pisze S. Kozłowski „ekorozwój polega na optymalnym wykorzystaniu zasobów i walorów środowiska przyrodniczego, ale zgodnie z zasadami jego naturalnego funkcjonowania. Zatem gospodarowanie przyrodą to gospodarowanie ekosystemami w sposób nie niszczący ich równowagi”’3.

Autor Ekorozwoju zwraca uwagę na możliwości unikania niepotrzebnych kosztów, jakie tkwią w sposobach gospodarowania, uwzględniających właściwe wykorzystanie zasobów przyrody. Niszcząc ekosystemy, niewspółmiernie zwiększają się koszty finansowe pochłaniane przez ich odtwarzanie. Przebieg rozwoju gospodarczego, zgodnego z ekorozwojem, nie powinien naruszać, poprzez godzenie w prawa przyrody i ekonomii, w sposób istotny i nieodwracalny środowiska życia człowieka. Optymalnym rozwiązaniem jest tu dążenie do wytworzenia stanu równowagi pomiędzy rozwojem gospodarczym a środowiskiem przyrodniczym. Możliwe jest to dzięki włączeniu ochrony tego środowiska w nurt działalności człowieka związany z produkcją materialną, ze wszystkimi tego kon-

2 Por. D.H. Meadows, D. L. Meadows, J. Randers, Przekraczanie granic. Globalne załamanie czy bezpieczna przyszłość?, w serii: Biblioteka Dialogu; Centrum Uniwersalizmu przy Uniwersytecie Warszawskim i Polskie Tow. Współpracy z Klubem Rzymskim, Warszawa 1995.

3 S. KozŁowski, Ekorozwój. Wyzwanie XXI wieku, Warszawa 2002, s. 107. Por. Tenże Polityka ekologiczna państwa 1989 - 2000 - ujęcie historyczne, w: Polityka ekologiczna III Rzeczypospolitej, pod red. A. Papuzińskiego, Bydgoszcz 2000, ss. 37 - 87. 
sekwencjami dla systemu finansowego, polityki cen, rachunku ekonomicznego przedsiębiorstw itp. W takiej sytuacji większe nakłady na ochronę i kształtowanie środowiska nie będą traktowane jako obciążające dochód narodowy, lecz jako czynnik jego wzrostu.

\section{Etapy i cele ekorozwoju}

Istotnym celem ekorozwoju jest zaspokajanie fizycznych i psychicznych potrzeb człowieka, ugruntowane na prawidłowych relacjach społeczeństwa ze środowiskiem przyrodniczym. Zwraca się przy tym uwagę na zapewnienie przyrodniczych podstaw egzystencji człowieka oraz na potrzebę wprowadzania ładu gospodarczego, funkcjonalnego i estetycznego w środowisku wynikającego z wdrażania zasad ekorozwoju.

S. Kozłowski wskazuje na przebieg procesu ekorozwoju dzieląc go na kilka podstawowych etapów. W pierwszym etapie następuje programowanie celów, dotyczących przede wszystkim rozwoju człowieka. Powinna być tu ujmowana istota odczuć i pragnień oraz potrzeby człowieka. Znajduje się to w zakresie problematyki humanistycznej podporządkowanej zasadom etyki. Akcentuje się w tym miejscu potrzebę „ascezy ekologicznej” jako przeciwieństwa postaw konsumpcyjnych. Ograniczoność zasobów naturalnych, wobec stale rosnącego zaludnienia, wymaga oszczędnego i racjonalnego gospodarowania nimi ${ }^{4}$.

Kolejny etap obejmuje badanie środowiska przyrodniczego. Postuluje się w tym miejscu położenie nacisku na badania syntetyzujące i systemowe, jako uzupełnienie, a nawet zamiana dotychczasowych metod badań przyrodniczych - badań empirycznych opartych wyłącznie na kryteriach naukowych. Pociąga to za sobą potrzebę rozszerzenia klasycznego ujęcia ekologii. Zwraca się przy tym uwagę na konieczność sprawnego określenia praw rządzących funkcjonowaniem przyrody i zachowaniem jej równowagi (homeostazy). Związane jest to z powszechną wiedzą na temat skutków naruszania stanów równowagi występujących w przyrodzie. Przekraczanie progów naturalnej odporności ekosystemów prowadzi do powstawania obszarów ekologicznego zagrożenia, a następnie do katastrof ekologicznych. Ekorozwój zakłada nie tylko gospodarowanie, które nie degraduje zasobów przyrody, ale wręcz przyczynia się do ich rozwoju i ulepszenia.

Kolejny etap związany jest $\mathrm{z}$ prognozowaniem zmian $\mathrm{w}$ środowisku (ang. Environmental Impact Assessment - EIA). Jest to nowa dziedzina nauki, w języku polskim oznacza ocenę oddziaływania na środowisko (OOS). Dla każdego zamierzenia inwestycyjnego, już na etapie programowania, sporządzania założeń techniczno - ekonomicznych, jak i szczegółowych projektów realizacyjnych inwestycji winna być wykonana OOS. Ocena taka obejmuje poszczególne warian-

\footnotetext{
4 Por. J. Aleksandrowicz, Sumienie ekologiczne, Warszawa 1988.
} 
ty lokalizacyjne i technologiczne. Pozwala więc wybrać najlepsze rozwiązanie, a jednocześnie uniknąć następujących problemów związanych z przeprowadzaną inwestycją:

- naruszania lub uszczuplania zasobów i walorów środowiska przyrodniczego i kulturalnego;

- wzrostu kosztów adaptacji zasobów środowiskowych do prowadzenia działalności;

- sytuacji konfliktowych wynikających z utraty lub pogorszenia jakości jakiegoś elementu środowiska, ważnego dla innego użytkownika;

- tworzenia i eliminowania barier środowiskowych;

- niedopasowania działalności do warunków i cech środowiska; powodowania potencjalnych zagrożeń zdrowotnych.

Końcowym etapem są działania realizacyjne. Idea ekorozwoju nabiera w tym miejscu znaczenia praktycznego. Jest to bardzo istotny moment, jeśli idea ekorozwoju ma zastąpić dominujące w gospodarce światowej podejście konsumpcyjne. S. Kozłowski wyróżnia w tym miejscu następujące etapy stosunku społeczeństwa do przyrody:

I. Okres technokratyzmu przyrodniczego - polega na eksploatacji i niszczeniu zasobów przyrody. Proces ten ulega przyspieszeniu wraz ze wzrostem degradacji. Przekroczenie dopuszczalnych progów przyrodniczych powoduje załamanie się odporności systemów zwane katastrofą ekologiczną.

II. Okres minimum ekologicznego - wyhamowania procesów niszczących. W tym okresie możliwe jest uruchomienie mechanizmów samoregulujących przyrody i rozpoczęcie samorzutnej odbudowy środowiska przyrodniczego.

III. Okres ekorozwoju - do rozwoju społeczno - gospodarczego wprzęgnięte zostają siły przyrody. Funkcjonowanie przyrody będzie, w tym okresie, stymulowane i sterowane na podstawie rządzących nią praw ekologicznych.

„Wobec konieczności stopniowego, uporczywego wprowadzania koncepcji ekorozwoju do sfery nauki, ekonomii, gospodarki, a także do myślenia i działania poszczególnego człowieka, niezbędna jest pełna znajomość ogólnych zasad i praw ekorozwoju ${ }^{5 "}$

Jak podkreśla S. Kozłowski, ekorozwój jest przeciwstawny dotychczas urzeczywistnianemu mechanistycznemu modelowi rozwoju. Taki rozwój prowadził raczej do niedorozwoju ekonomicznego, kulturowego czy politycznego.

W latach siedemdziesiątych dwudziestego stulecia wprowadzona została i sprecyzowana w roku 1987, w tzw. Raporcie Brundtland, koncepcja zrównoważonego rozwoju. Zrównoważony rozwój odpowiada potrzebom dzisiejszego pokolenia, nie zagrażając możliwościom przyszłych pokoleń, zaspokajając potrzeby obecne i przyszłe. Bazuje na dwóch podstawowych założeniach:

S. KozŁowski, Ekorozwój. Wyzwanie XXI wieku, Warszawa 2002, s. 112. 
- W pierwszej kolejności należy skupić się na koncepcji potrzeb, w szczególności podstawowych potrzeb najbiedniejszych.

- Przy zaspokajaniu aktualnych i przyszłych potrzeb trzeba uwzględnić również ograniczone możliwości, nie ignorować granic wyznaczanych postępowi techniki i społecznego porządku przez środowisko naturalne.

Zrównoważony rozwój Ziemi to rozwój zaspokajający podstawowe potrzeby wszystkich ludzi, a jednocześnie dbający o ochronę, zachowanie i odnowę zdrowia i integralności systemów ekologicznych Ziemi, bez ryzyka, że potrzeby przyszłych pokoleń nie będą mogły być zaspokojone, a granice wytrzymałości Ziemi zostaną przekroczone. Koncepcja ta ma stanowić podstawę niezakłóconego bytowania społecznego oraz trwałego i sprawiedliwego rozwoju. Jednocześnie zapewnia:

a) trwałość ekologiczną,

b) rozwój ekonomiczny,

c) sprawiedliwość społeczną między pokoleniami i w obrębie każdego pokolenia ${ }^{6}$. Uznaje się przy tym, że do promowania trwałości rozwoju niezbędne jest określenie następujących celów polityki środowiskowej i gospodarczej:

a) ożywienie wzrostu gospodarczego;

b) zmiana jakości wzrostu;

c) zaspokojenie podstawowych potrzeb ludzkich w zakresie pracy, pożywienia, energii i higieny;

d) stabilizacja liczby ludności;

e) ochrona i pomnażanie bogactw naturalnych;

f) zmiana profilu technologii oraz metod zarządzania ryzykiem;

g) kojarzenie praw ekologii i ekonomii w procesie decyzyjnym? ${ }^{7}$.

Wśród podstawowych założeń strategii, które powinny być przyjęte i realizowane wskazuje się na:

a) realizację pożądanych celów społecznych;

b) wzrost realnego dochodu per capita;

c) poprawę stanu zdrowotnego i poziomu wyżywienia;

d) uczciwy dostęp do zasobów środowiska przyrodniczego;

e) poprawę poziomu wykształcenia.

Podstawowe reguły zarządzania rozwoju zrównoważonego obejmują następujące założenia:

- Wykorzystanie odnawialnych zasobów nie powinno przekraczać ich regeneracji.

- Wykorzystanie nieodnawialnych surowców nie powinno przewyższać odbudowy odnawialnych surowców.

\footnotetext{
6 Por. Raport Światowej Komisji do Spraw Środowiska i Rozwoju pod przewodnictwem G. H. BRUndTLAND, Nasza wspólna przyszłość, Warszawa 1991.

7 S. KozŁowski, Ekorozwój. Wyzwanie XXI wieku, Warszawa 2002, ss. 113 - 114.
} 
- Emisja szkodliwych substancji nie powinna przewyższać naturalnej pojemności w zakresie absorpcji szkodliwych substancji.

W koncepcji zrównoważonego rozwoju zwraca uwagę postulat utrzymywania równowagi między dwoma podstawowymi systemami: przyrodniczym i społecznym. Zachowanie takiej równowagi zakłada konieczność poznania i sterowania procesami przyrodniczymi i społecznymi. Znaczącą rolę odgrywa tu wpływ rozwoju gospodarczego na przyrodę. Aby realizowane mogły być podstawowe założenia zrównoważonego rozwoju postuluje się opracowanie strategii rozwoju społeczeństwa. Strategie takie powinny być konstruowane z uwzględnieniem zróżnicowania systemów przyrodniczych i społecznych. Zwłaszcza strategie narodowe winny uwzględniać specyfikę lokalnych stosunków przyrodniczych i społecznych ${ }^{8}$. Jak wynika z powyższego, przyjęcie jednego wzorca kulturowo - gospodarczego stanowi zagrożenie dla realizacji założeń zrównoważonego rozwoju. Dominujące obecnie wzorce (cywilizacji zachodniej) okazują się nieadekwatne lub wręcz niebezpieczne w wielu przypadkach (kraje arabskie).

\section{Zasady i prawa ekorozwoju}

Ograniczoność zasobów Ziemi odgrywa istotną rolę w projektowaniu strategii rozwoju. Panujący obecnie model wzrostu produkcji i konsumpcji (niemal nieograniczonych) winien być zamieniany na model uwzględniający jak najmniejsze zużycie materiałów i energii. S. Kozłowski dostrzega wdrażanie takiego modelu w zakresie minimalizacji rozmiarów obwodów scalonych (stosowanych na przykład w komputerach) i określa jako nadchodzącą rewolucję efektywności. $\mathrm{W}$ dalszej perspektywie strategie ekorozwojowe, zdaniem S. Kozłowskiego, winny funkcjonować w wymiarach globalnym, narodowym, regionalnym i lokalnym. W skali globalnej postulowana jest konieczność zmiany stylu życia i wdrażanie nowych technologii - ekologicznie bezpiecznych, czystych. Jednocześnie istotne jest tu wdrażanie technologii nowego typu jakimi są technologie informacyjne. Należy również, w tym miejscu, wymienić za S. Kozłowskim szereg podstawowych zasad, jakie należy brać pod uwagę w strategii zrównoważonego rozwoju:

a) Kompatybilność: równoczesne i równomierne uwzględnienie celów ekonomicznych, ekologicznych i społecznych.

b) Możliwość wprowadzania do praktyki: realistyczne i ogólnie zrozumiałe działania, nie przekraczające istniejących możliwości przyjęcia i efektywności systemów sterowania, winny odznaczać się trwałością.

\footnotetext{
8 Por. Ocena zrównoważonego rozwoju (ekorozwoju) w procesie transformacji polskiej gospodarki. Ekspertyza, pod red. S. Kozłowskiego, Człowiek i środowisko przy prezydium PAN, Zeszyty Naukowe 30, Warszawa 2002.
} 
c) Zdolność do włączenia: przy określaniu celów, instrumentów, środków i praktyki należy uwzględniać istniejące wymogi społeczno - kulturowe, normy i sposoby zachowania.

d) Odwracalność: możliwość rezygnacji z dotychczasowych celów, instrumentów, środków i praktyk, w sytuacji, gdy pojawi się nowa wiedza w zakresie ekorozwoju.

e) Elastyczność: zmienione cele, instrumenty, środki i praktyki powinny być wprowadzone w możliwie krótkim czasie.

f) Efektywność: ustalone cele należy wprowadzać w przyjętych terminach.

g) Wydajność: trwałe gospodarowanie (gospodarcze, techniczne, ekologiczne i społeczne) powinno znajdować nakłady proporcjonalne do pożądanych efektów.

h) Ograniczoność: preferuje się dążenie do polepszania jakości życia, w przeciwieństwie do dążenia aby było „coraz więcej tego samego”.

i) Zgodność: zamknięty obieg materii i energii - zasoby nie mogą się ciągle powiększać9.

Można powiedzieć, że zasadniczym dążeniem, w ramach ekorozwoju, jest określenie środków i warunków niezbędnych do długotrwałego zachowania funkcji systemu ekologicznego związanych ze światem organicznym. Nie mniej istotne są tu kwestie społeczne takie jak: sprawiedliwość, dobrobyt czy bezpieczeństwo.

Dotychczas stosowane mierniki wzrostu PKB nie uwzględniają szybkiego zużywania zasobów przyrody. Taki sposób pomiaru nie uwzględnia zasad ekorozwoju, winien być zatem uzupełniony - na przykład wskaźnikiem dotyczącym rozwoju ludności (ang. Human Development Index - HDI). Zawiera on następujące składniki:

a) długość oczekiwanego życia w momencie narodzin;

b) wiedza, wykształcenie, dostęp do oświaty;

c) dochód wyrażany wielkością produktu krajowego brutto na mieszkańca.

Dodatkowo dla potrzeb sterowania procesami sprzyjającymi zrównoważonemu rozwojowi opracowano inne wskaźniki środowiskowe ${ }^{10}$.

Oprócz zasad podstawowych S. Kozłowski prezentuje ogólne zasady ekorozwoju:

a) Zasada główna ekorozwoju - ustala jednoznacznie, że obowiązek ochrony środowiska nie może pozostawać $\mathrm{w}$ konflikcie $\mathrm{z}$ interesami gospodarki. Obowiązek ten jest natomiast elementem prawidłowego gospodarowania. Wszelka działalność naruszająca ten obowiązek jest bezwzględnie nielegalna.

\footnotetext{
9 S. KozŁowski, Ekorozwój. Wyzwanie XXI wieku, Warszawa 2002, ss. 118.

10 Szerzej na ten temat: S. KozŁowski, Ekorozwój. Wyzwanie XXI wieku, Warszawa 2002, ss. 120 $-123$.
} 
b) Zasada uwzględniania wymogów środowiska w działalności planistycznej dotyczy zwiększenia, w planowaniu przestrzennym, znaczenia problemów gospodarowania zasobami środowiska.

c) Zasada praworządności - wskazuje, że przepisy prawne powinny być ściśle przestrzegane, bez odstępstw i wyjątków. Zasada zakłada nie przekraczanie ustalonej prawnie lub administracyjnie skali ingerencji w środowisko.

d) Zasada odpowiedzialności sprawcy - zakłada się tu pełną odpowiedzialność materialną za skutki degradacji środowiska (zanieczyszczający płaci). Zasada ta nie ogranicza się do producentów czy usługodawców, ale również każdej jednostki organizującej życie obywateli (spółdzielni mieszkaniowych, przedsiębiorstw komunalnych, gmin itp.), jak i każdego obywatela (gospodarstwa domowego).

e) Zasada likwidacji zanieczyszczeń u źródła - zaleca się tu unikania wytwarzania zanieczyszczeń, oraz stosowania obiegów zamkniętych (recykling).

f) Zasada ekonomizacji - winna łączyć mechanizmy rynkowe z zachowaniem niezbędnego interwencjonizmu rynkowego.

g) Zasada regionalizmu - dotyczy ona następujących obszarów:

- ekologicznego zagrożenia,

- obszarów o dużych walorach przyrodniczych,

- obszarów pośrednich.

Zakłada się tu prawo każdego regionu do własnej polityki społeczno - gospodarczej i ekologicznej.

h) Zasada uspołecznienia - zakłada tworzenie instytucjonalnych i prawnych warunków udziału obywateli, grup społecznych i organizacji pozarządowych w całym procesie ochrony i kształtowania środowiska. Realizowane winny być programy edukacji ekologicznej, budzenie świadomości i wrażliwości ekologicznej oraz budowanie nowej etyki zachowań wobec środowiska.

i) Zasada wspólnego rozwiązywania europejskich i globalnych problemów ochrony środowiska - oznacza konieczność ścisłej współpracy międzynarodowej ${ }^{11}$.

S. Kozłowski prezentuje również prawa ekorozwoju. Pierwsze z nich - prawo celu - mówi o tym, że każda działalność człowieka musi uwzględniać uwarunkowania przyrodnicze. Dokładniej rzecz ujmując - w podejmowaniu decyzji gospodarczych nie należy kierować się wyłącznie kryteriami ekonomicznymi, ale również ekologicznymi. Działalność człowieka powinna charakteryzować się rozumnym sposobem korzystania z zasobów przyrody a nie doprowadzać do niszczenia i degradacji środowiska. S. Kozłowski postuluje nawet, aby zaniechać takich działań, które wydają się, z punktu widzenia ekonomicznego, celowe, zaś mogłyby przyczynić się do zaburzania procesów zachodzących w biosferze.

11 Zasady ustalone zgodnie z Polityka Ekologiczna Państwa z roku 1990. Cyt. za S. KozŁowski, Ekorozwój. Wyzwanie XXI wieku, Warszawa 2002, ss. 127 - 129. 
Kolejne prawo to prawo skali i jakości. Lekceważenie jakości środowiska doprowadziło do ogromnych jego zatruć przez odpady gazowe, ciekłe i stałe. Zasoby przyrody, w skali świata, okazały się być ograniczone. Coraz częściej zaczęto przekraczać, zarówno ilościowe jak i jakościowe, naturalne bariery ich eksploatacji. Przekroczenie tych barier prowadziło do kryzysów, względnie nawet katastrof ekologicznych. Nastąpił upadek mitu o powszechnej łatwości i dostępie do zasobów przyrody. Niemniej obecnie uznawane prawa rynku i ekonomii nie znają mechanizmów samoograniczjących się. Dąży się natomiast do stałego powiększania skali działań i zysków ekonomicznych. Drugie prawo dotyczy właśnie skali i jakości podejmowanych działań gospodarczych. W takim ujęciu wprowadzane są regulacje mające na celu unikanie przekraczania naturalnych barier środowiskowych. Postuluje się przy tym, aby „dać szansę” naturalnym procesom samoregulacji niwelującym skutki działalności człowieka.

Ostatnie, wymienione przez S. Kozłowskiego, prawo ekorozwoju dotyczy kwestii rozwoju regionalnego i określane jest jako prawo regionu. Rozwój taki powinien uwzględniać uwarunkowania przyrodnicze i społeczne. Wskazuje się na odejście do unifikacji zadań i programów prowadzonych w skali całego kraju na rzecz akcentowania specyfiki urbanistycznej, kulturowej, przemysłowej, rolniczej czy przyrodniczej w procesach decyzyjnych - rozwojowych.

Wskazywane prawa i zasady ekorozwoju wydają się być w pełni kompatybilne z coraz bardziej popularnymi w Polsce Systemami Zarządzania Środowiskowego. Systemy te mogą być uznane za praktyczne metody wdrażania idei Ekorozwoju.

\section{Problematyka moralna w koncepcji ekorozwoju}

Wśród akcentowanych przez S. Kozłowskiego celów, zasad i programów ekorozwoju znaczące miejsce zajmuje tematyka etyczno - moralna.

W sytuacji konieczności wyjścia z kryzysu ekologicznego zdaniem S. Kozłowskiego zaproponowano tylko jedną ogólną koncepcję, dalszego harmonijnego wzrostu społeczno - gospodarczo - ekonomicznego świata. Jest nią koncepcja zrównoważonego rozwoju. Niemniej, aby osiągnąć w pełni realizację proponowanego w tej koncepcji modelu świata, konieczne jest zwrócenie bacznej uwagi na kreowanie odpowiednich postaw moralnych i stylu życia, zaś w kształtowaniu państwa ekologicznego przyjąć nowe cele.

Główne przesłanki wprowadzania nowego ładu moralnego odnoszą się do globalnej ochrony środowiska, która jest już nie tylko sprawą najwyższej rangi, ale szansą przeżycia. Odnoszą się także do ustalenia niekwestionowanej pozycji osoby ludzkiej i wynikających stąd założeń nienaruszalności jej podstawowych praw - to ona ma przeżyć ${ }^{12}$.

12 S. KozŁowski, Ekorozwój. Wyzwanie XXI wieku, Warszawa 2002, s. 334 
Konsekwencją przyjęcia tych założeń jest konieczność respektowania zasad: a) personalizmu - porządek prawny w systemie demokratycznym i politycznym jest zdecydowanie antropocentryczny. Zakłada jednocześnie, że natura osoby ludzkiej w odniesieniu do świata przyrody ożywionej i nieożywionej jest racjonalna,

b) solidarności - dotyczy relacji między bogatymi i ubogimi oraz dewastacji środowiska. Oznacza również solidarność z przyszłymi pokoleniami.

c) retynizacji (sieć powiązań wzajemnych) - mówi o konieczności współzależnego traktowania sieci powiązań trzech czynników: ekonomicznego, społecznego i ekologicznego.

Zwraca się przy tym uwagę na konieczność określenia etyki teraźniejszości zwróconej jednocześnie ku przyszłości. W ten sposób winna powstać ekoetyka - linia przewodnia postępowania. Naczelnym jej postulatem jest potrzeba łącznego traktowania człowieka i środowiska. Ekoetyka formułuje specyficzne zasady postępowania człowieka. Pierwszą z nich jest zasada nowej jakości ludzkiego życia. Według niej na pierwszym planie jest człowiek i jego wewnętrzny rozwój. Jednocześnie dobrobyt nie może być mierzony jedynie wskaźnikami produkcji i konsumpcji. Kolejną jest zasada szacunku dla przyrody. Zmierza ona do eliminacji postaw bezmyślności i dowolności w korzystaniu z zasobów przyrody. Ostatnia $\mathrm{z}$ wymienionych zasad mówi o traktowaniu środowiska przyrodniczego jako dobra wspólnego. Zakłada eliminację działań prowadzących do zawłaszczania zasobów przyrody przez korporacje czy poszczególne osoby.

\section{Ekofilozoficzne źródła ekorozwoju}

Profesor Kozłowski uznaje istotną rolę ekofilozofii w kształtowaniu odpowiednich postaw skierowanych ku ekorozwojowi. Wskazuje na jej rolę w formułowaniu założeń dla nadchodzącej ery ekologicznej. Wśród tych założeń wyróżnia konieczność kształtowania myślenia "planetarnego” w wymiarze indywidualnym i ogólnospołecznym, dotyczącego dobra całej ziemi i ludzkości. Zwraca uwagę, na postulat budowania nowej etyki, uwzględniającej poszanowanie wszelkiego życia i całości ekosystemu ziemskiego. W podejściu tym istotną rolę pełni zrozumienie tego, że przyroda nie jest tylko surowcem do wykorzystania, ale ma wartości estetyczne czy wręcz metafizyczne. $\mathrm{W}$ takim ujęciu człowiek i jego rola w świecie zyskuje nową perspektywę. Przestaje być on bowiem „konkwistadorem” antropocentryzmu ery przemysłowej, staje się zaś „,sternikiem”, „pasterzem”, „dobrym gospodarzem”. W ten sposób kształtuje się podejście ekocentryczne. Podejście takie zmienia również pojęcie dobrobytu, które przechodzi od wskaźników ilościowych do jakościowych. Poszerzeniu ulega, w tym kontekście, stosunek do sposobu samorealizacji człowieka, który jest płodny nie tylko fizycznie, ale również duchowo i kulturalnie. 
Nową perspektywę zyskują odniesienia do nauki i techniki, które postrzega się już nie tylko jako narzędzia opanowywania, podboju przyrody, ale jako dające możliwość zachowania i rozwoju biosfery. Stają się wyzwaniem i odpowiedzią na nieprzewidywalność przyszłości. Zagadnienia te pojawiają się w kontekście prognozowania, zarządzania czy też procesów decyzyjnych.

Coraz większe znaczenie w takiej perspektywie zyskuje nowa orientacja egzystencjalna związana z filozofią i religią ukazującymi jak i po co żyć. Orientację taką Bogdan Suchodolski nazywa duchową cywilizacją uniwersalną. ,Jest to cywilizacja wartości powszechnych jawiących się w różnorodności kultur świata - historycznych i współczesnych - jako tożsamość ludzkiego rodu. Jest to cywilizacja, w której wspólnota łączy ludzi głębiej i silniej niż organizacja, a kształt życia godny człowieka jest ważniejszy niż krótkotrwałe relacje pragmatyczne. Jest to cywilizacja, w której kultura jest powagą i radością jako wielkie dzieło sił twórczych ludzkości, stwarzającej na łonie przyrody swe własne królestwo ${ }^{13}$ ". Dostrzegalne jest, w koncepcji uniwersalnej cywilizacji humanistycznej, przeciwstawienie rozwijanej cywilizacji o charakterze utylitarnym, pragmatycznym, kosmopolitycznym i konsumpcyjnym. U podstaw pierwszej leżą, wcześniej wspomniane, zasady ekoetyki i ekofilozofii, u podstaw drugiej mechanistyczny i utylitarystyczny obraz świata.

W rozważaniach dotyczących ekorozwoju S. Kozłowski zwraca uwagę na problem stylu życia, który dominował w społeczeństwie. Wyróżnia przy tym następujące po sobie etapy. Pierwszym z nich jest, dominujący obecnie, etap gospodarki materialnej. Główną jego cechą jest chęć posiadania i gromadzenia dóbr. Obowiązuje tu zatem zasada - więcej produkować, więcej zużywać. Pomimo istotnych różnic pomiędzy bogatą Północą a biednym Południem, na tym etapie znajduje się większość krajów rozwiniętych. Gospodarka materialna nastawiona jest głównie na maksymalizację zysków. Wysiłek społeczno - polityczny skupia się na powiększaniu wzrostu gospodarczego, realizowanego kosztem zużywania i degradacji środowiska, w którym żyjemy.

Drugi etap określany jest przez S. Kozłowskiego, jako etap gospodarki usług. Z tym etapem mamy obecnie już do czynienia w krajach o najwyższym stopniu rozwoju społeczno - gospodarczego. Na tym etapie maleje grupa robotników zatrudnionych przy produkcji, natomiast rozwijana jest coraz bardziej sfera usług. Zamiast niedoborów pojawia się nadmiar - nadprodukcja różnorodności. Dotyczy to nie tylko towarów, ale również orientacji politycznych, społecznych, religijnych, filozoficznych. Tym samym zwiększa się zróżnicowanie stylów życia. W gospodarce winna zacząć dominować zasada „produkować więcej, zużywać

13 Cyt. za S. KozŁowski, Ekorozwój. Wyzwanie XXI wieku, Warszawa 2002, s. 336, B. Suchodolski, Dwie cywilizacje uniwersalne, w: Strategia obrony i rozwoju cywilizacji humanistycznej. Kom. Prognoz „Polska w XXI wieku”, Warszawa 1997. 
mniej”. Chodzi tu o mniejsze zużywanie zasobów przyrody, mniejsze zanieczyszczenie środowiska. Staje się to możliwe dzięki wprowadzaniu technologii energooszczędnych i bezodpadowych, miniaturyzacji techniki, większego udziału zasobów odnawialnych.

S. Kozłowski zauważa, że w wyniku realizującego się drugiego modelu gospodarki powstaje nowy układ społeczny odznaczający się coraz większą różnorodnością. Taka różnorodność jest w zasadniczej mierze oparta na wyższym stopniu indywidualnego rozwoju jednostki, na wyższym stopniu świadomości ekologicznej. Umożliwia to identyfikację i likwidację zagrożeń regionalnych i globalnych. Już na tym etapie, kluczowe znaczenie będą miały kształtowanie postaw i kształtowanie środowiska życia człowieka. Kształtowane postawy winny uwzględniać nową hierarchię wartości. Preferowane będą postawy odznaczające się samoograniczeniem, skromnością i powściągliwością. Nowy styl życia będzie promowany dzięki ogromnym możliwościom komunikowania się, a co za tym idzie wymianie myśli, poglądów, podróżowaniu, przeżywaniu różnego rodzaju doznań itp. Jak pisze $S$. Kozłowski „Na tym etapie najcenniejszą wartością będzie myśl”"14.

Niestety w Polsce ciągle jeszcze dominuje model maksymalnego gromadzenia dóbr. Zaszłości wynikające z poprzedniego systemu społeczno - gospodarczego Polski są olbrzymie i z pewnością jeszcze wiele czasu potrzeba, aby nasi obywatele zaspokoili swoje podstawowe potrzeby materialne. Dopiero wtedy można będzie mówić o próbach przejścia do drugiego, wskazywanego etapu rozwoju gospodarczego. $Z$ całą pewnością trudno mówić o samoograniczeniu, które jest jednym $\mathrm{z}$ istotnych elementów zrównoważonego rozwoju gospodarczo - społecznego komuś, kogo podstawowe potrzeby dalekie są od zaspokojenia. S. Kozłowski dostrzega problem braku i niedostatku, przede wszystkim artykułów żywnościowych. Szczególnie problem ten dostrzegany jest w przypadku niewłaściwych relacji między bogatą Północą a biednym Południem. Sytuację taką nazywa patologią dzisiejszego świata wywołaną ignorowaniem podstawowych założeń moralnych.

S. Kozłowski prezentuje wiele rozwiązań obecnej sytuacji kryzysowej wynikającej z przyjmowania, przestarzałych i nieadekwatnych do szybko zmieniającej się rzeczywistości, standardów gospodarowania i rozwoju. Zwraca uwagę na kwestie związane z redukcją zanieczyszczeń, zużyciem surowców i energii, wdrażania nowych technologii przyjaznych dla środowiska. Nad to wskazuje kierunki rozwiązań w zakresie podatków, decyzji politycznych związanych z organizacją państwa, organizacji społeczeństwa obywatelskiego, tworzenia ekologicznych funduszy. Poza tym postuluje potrzebę wprowadzania ogólnoświatowych standardów ekologicznych. Wskazuje też na potrzebę rozwoju coraz doskonalszych programów edukacyjnych obejmujących wysoki poziom kształcenia zarówno

14 S. KozŁowsкi, Ekorozwój. Wyzwanie XXI wieku, Warszawa 2002, s. 337. 
w zakresie nauk przyrodniczych, jak i humanistycznych, mających na celu zmianę postaw (kształtowanie świadomości i myślenia ekologicznego) i stylu życia (światopogląd ekologiczny, samoograniczenie, odpowiedzialność za środowisko społeczno - przyrodnicze obecne ale i przyszłych pokoleń). Ukazuje potrzebę realizowania programów innowacyjnych, mogących w znacznym stopniu przyczynić się do zmiany obecnej struktury gospodarki.

\section{Zakończenie}

W sposobie podejmowania przez S. Kozłowskiego problematyki ekorozwoju charakterystyczne jest podejście do szerokiego spektrum omawianych zagadnień (od politycznych, społecznych, gospodarczych aż po zagadnienia moralne czy etyczne). W wielu miejscach profesor Kozłowski odwołuje się do ujęć systemowych (przykłady badań nad zharmonizowanym rozwojem ${ }^{15}$ ), zwraca uwagę na potrzebę stosowania takiego ujęcia. W badaniach nad ekorozwojem często stosuje się modele systemów społeczno - techniczno - ekologicznych. W modelach takich uwzględniany jest zarówno czynnik ludzki, środowiskowy, techniczny czy technologiczny, jak i energia i obecnie coraz częściej informacja.

W związku z koniecznością uwzględniania w realizacji ekorozwoju długofalowych działań strategicznych, dotyczących głównie tradycyjnej ochrony środowiska, ale również odnoszących się do podstawowych mechanizmów gospodarki człowieka, powstaje nowy kierunek zwany sterowaniem ekologicznym.

Ujęcie Stefana Kozłowskiego obejmuje problematykę polityczną, ekonomiczną, gospodarczą, związaną z rozwojem nauki i techniki oraz problematykę relacji pomiędzy człowiekiem a przyrodą. W tym ujęciu określenie „ekorozwój” akcentuje znaczenie jakości i potrzebę ochrony środowiska przyrodniczego w procesie rozwoju cywilizacyjnego globalnej społeczności. W pracach autorstwa S. Kozłowskiego termin „ekorozwój” jest stosowany często zamiennie z terminem „rozwój zrównoważony”. Może to świadczyć o tym, że idea zrównoważonego rozwoju, według S. Kozłowskiego, nie może być realizowana w oderwaniu od szeroko rozumianej problematyki ekologicznej ${ }^{16}$.

15 S. KozŁowski, Ekorozwój. Wyzwanie XXI wieku, Warszawa 2002, ss. 129 - 133.

16 Informacje o Prof. dr hab. Stefanie Kozłowskim dostępne są na stronie internetowej pod adresem: http://pater.kul.lublin.pl/wystawy/vita_mutatur/2007/kozlowski/stefan_kozlowski. htm 


\section{The idea of eco-development in Stefan Kozłowski's works}

\section{SUMMARY}

There is a specific way of approaching sustainable development issues in S. Kozłowski’s works. He takes into account a wide spectrum of problems from political, social, economic ones to moral and ethical with reference to natural environment (ecodevelopment). Frequently, he refers to systemic approaches e.g. researches on harmonized development pointing out the need for using such a perspective. In the researches on sustainable development there are models including social, technical and ecological systems. The models take into account a human factor, environment, techniques as well as energy and information. As there is a need for including long term actions related to environmental protection as well as economic mechanisms to carry out sustainable development plans, a new tool emerged called ecological control.

Professor Stefan Kozłowski's approach towards sustainable development including relations between a human and nature accentuates the meaning of quality and need for natural environmental protection in a process of civilization development of a global society. In his works "eco-development" is used interchangeably with "sustainable development". Therefore according to S. Kozłowski the idea of sustainable development cannot be realise in isolation from ecological issues. 